\title{
Doskonalenie procesów w administracji publicznej z zastosowaniem lean government
}

\section{Streszczenie}

W opracowaniu zaprezentowano koncepcję lean government stosowaną w doskonaleniu funkcjonowania instytucji sektora publicznego. Zasygnalizowano obecne kierunki zmian w sektorze publicznym i nawiązano do koncepcji new public management. Następnie omówiono istotę lean government i przedstawiono klasyfikację strat z punktu widzenia specyfiki instytucji administracji publicznej. Zarysowano także podstawowe bariery wdrażania metod wykorzystywanych dotychczas w doskonaleniu organizacji komercyjnych, jak również przedstawiono wskazówki dotyczące stosowania podejścia lean $\mathrm{w}$ organizacjach sektora publicznego. W ramach podsumowania podkreślono konieczność stosowania omawianej koncepcji w Polsce.

Słowa kluczowe: administracja publiczna, lean government, new public management, usprawnianie procesów.

Klasyfikacja JEL: D73, H83, L33, M11.

\section{Wprowadzenie}

Zamierzonym efektem doskonalenia procesów w administracji publicznej, w tym szeroko rozumianych procesów zarządzania, jest podnoszenie sprawności

Maciej Walczak, Uniwersytet Ekonomiczny w Krakowie, Wydział Zarządzania, Katedra Metod Organizacji i Zarządzania, 31-510 Kraków, ul. Rakowicka 27, e-mail: walczakm@uek.krakow.pl

* Artykuł powstał w wyniku realizacji tematu badawczego finansowanego ze środków przyznanych Wydziałowi Zarządzania Uniwersytetu Ekonomicznego w Krakowie w ramach dotacji na utrzymanie potencjału badawczego. 
świadczenia usług publicznych ${ }^{1}$ [Sasak 2013, s. 192]. A. Grycuk kładzie nacisk na kwestie ekonomiczne i jakościowe. Autor ten podkreśla, że zmiany, jakie są podejmowane od ponad 20 lat w sektorze publicznym, mają na celu poprawę efektywności działania, jak również obniżenie kosztów funkcjonowania tego sektora w państwie. Dlatego powinny spełniać oczekiwania obywateli odnośnie do poprawy jakości funkcjonowania administracji publicznej przy warunku pozostawienia obciążeń podatkowych na dotychczasowym poziomie [Grycuk 2011, s. 1].

Celem niniejszego opracowania jest ukazanie lean government, pochodnej popularnego $\mathrm{w}$ przedsiębiorstwach ${ }^{2}$ tzw. zarządzania odchudzonego (lean management), jako koncepcji mogącej zmienić podejście do funkcjonowania organizacji sektora publicznego oraz wyznaczyć główne kierunki działania w jego usprawnianiu.

W opracowaniu przyjęto, że podstawowe założenia koncepcji zarządzania odchudzonego mogą stać się podstawą racjonalizacji procesów w sektorze publicznym. Możliwe jest również wykorzystanie w tym celu narzędzi koncepcji lean. Pożądane usprawnienia procesów to takie, które znajdą odzwierciedlenie m.in.: w krótszym czasie realizacji spraw, zmniejszeniu pracochłonności procesów, wzroście wydajności pracy personelu oraz wyższym poziomie zadowolenia klientów. Wdrożenia lean w omawianym obszarze wymagać będą jednak uwzględnienia zestawu wytycznych implementacyjnych związanych z odmiennością analizowanego sektora. Ponadto należy się spodziewać, że osiągnięty wzrost efektywności działania będzie niższy niż w przypadku organizacji komercyjnych.

Zastosowaną metodą badawczą były studia literatury krajowej i zagranicznej.

\section{Przenikanie metod i koncepcji zarządzania z przedsiębiorstw do sektora publicznego $\mathrm{w}$ ramach new public management}

Termin new public management (NPM) powstał na początku lat 90. XX w. Mianem tym określono próby stosowania w administracji publicznej metod i technik zarządzania sprawdzonych w sektorze komercyjnym. Efektem miało być podniesienie sprawności funkcjonowania administracji, w tym w szczególności

1 Za podstawowe wymiary sprawności należy przyjąć: skuteczność - stopień zgodności osiąganych efektów z założonymi celami, efektywność (w tym ekonomiczność) - stosunek efektów do nakładów ponoszonych na ich osiągnięcie (rozpatrywanych w wymiarze materialnym i moralnym), korzystność - różnica pomiędzy użytecznymi wynikami działania a kosztami z nimi powiązanymi [Sasak 2013, s. 192].

2 Przedsiębiorstwach rozumianych w sensie organizacji nastawionych na generowanie zysku. 
poprawa wykorzystania środków budżetowych przy realizacji wyznaczonych jej celów [Izdebski 2007, s. 12]. H. Izdebski już w 2007 r. odniósł się do NPM w kategoriach czasu przeszłego, zwracając uwagę na rozczarowanie ideologią liberalną, dostrzeganie złożoności funkcjonowania wielkich organizacji (do których należy administracja publiczna), wykluczającej wskazanie jednej najlepszej drogi postępowania, niepodważalne różnice między sektorem publicznym a komercyjnym (nadrzędnym celem tej pierwszej jest świadczenie usług powszechnych, a nie usług efektywnych ekonomicznie - jak w przypadku tych drugich) [Izdebski 2007, s. 14]. Autor ten podkreśla jednak, że wiele elementów NPM, do których należy zaliczyć m.in.: zwracanie większej uwagi na aspekty finansowe podejmowanych działań, wyznaczanie zadań i kontrolę efektów ich wykonania, wykorzystanie outsourcingu czy też zarządzanie jakością, zachowuje w odniesieniu do administracji publicznej swoją aktualność [Izdebski 2007, s. 14]. Warte podkreślenia są również postulaty przejrzystości działania, traktowanie obywateli jak klientów, nowe rozwiązania w zakresie zatrudniania, wynagradzania i premiowania pracowników czy też tworzenie warunków rozwoju konkurencji wśród dostawców usług publicznych [Grycuk 2011, s. 1]. Ważnym postulatem było adaptowanie rozwiązań wypróbowanych wcześniej w sektorze komercyjnym do zarządzania $\mathrm{w}$ administracji. Wśród rozwiązań wprowadzanych $\mathrm{w}$ instytucjach administracji państwowej, samorządowej oraz służby zdrowia, wielokrotnie wykorzystywanych w celu poprawy realizacji procesów, znalazły się: lean thinking, six sigma, business process reengineering, kaizen i total quality management. W opracowaniach na temat stosowania wyżej wymienionych narzędzi w sektorze publicznym najczęściej wskazywana była koncepcja lean (51\% procent wskazań w przypadku administracji i 35\% w odniesieniu do służby zdrowia) [Radnor i Osborne 2013, s. 265-266].

Według M. Lisińskiego i B. Ostrowskiego lean management odnosi się do „paradygmatu dotyczącego sposobu myślenia o tworzeniu wartości z punktu widzenia klienta i eliminacji marnotrawstwa w trakcie procesów produkcyjnych" [Lisiński i Ostrowski 2006, s. 45]. Koncepcję tę należy rozpatrywać jako system zarządzania, w którym dąży się, przez nieustanną eliminację marnotrawstwa, do zoptymalizowania procesów tworzenia i przepływu wartości w przedsiębiorstwie. Celem lean management jest wbudowanie jakości w proces wytwarzania $\mathrm{z}$ jednoczesnym przyjęciem zasady redukcji kosztów. T. Ohno, jeden z twórców systemu produkcyjnego Toyoty, również uważa, że zasadniczym celem prowadzenia działań „wyszczuplających” w przedsiębiorstwie jest zwiększenie wydajności pracy przez dokładne i stopniowe eliminowanie tzw. mudy ${ }^{3}$.

3 „Muda” w języku japońskim oznacza wszelkiego rodzaju marnotrawstwo, zarówno w rozumieniu produkowania braków i odpadów, jak również w podejmowaniu działań, które nie tworzą wartości [Ćwiklicki 2004, s. 117]. 
U podstaw lean management leży przede wszystkim dążenie do eliminacji marnotrawstwa. Eliminację tę osiąga się przez wykorzystanie metod i technik pełniących funkcję pomocniczą względem całego systemu. Zasadnicze znaczenie dla prawidłowego funkcjonowania całego systemu mają jednak ludzie, którzy muszą cechować się wysokimi kwalifikacjami i poczuciem odpowiedzialności za jakość realizowanych procesów. Dlatego też od ludzi wymaga się odpowiedniej postawy moralnej, zdyscyplinowania, nieustannego rozwoju i pracy zespołowej. Oznacza to, o czym łatwo zapomnieć, że ważne są nie tylko rozwiązania organizacyjne.

\section{Najważniejsze elementy koncepcji lean government}

Próbując zwięźle zdefiniować lean government, koncepcję tę można określić jako szczupłe zarządzanie w sektorze publicznym. Wykorzystuje ona filozofię i narzędzia pierwotnie stworzone lub zaadaptowane na potrzeby lean management, ale odpowiednio dostosowane do potrzeb administracji publicznej [Grycuk 2011, s. 1]. Celem jej stosowania jest „dostarczenie obywatelom oczekiwanej przez nich wartości zgodnie z zasadami i metodami lean" [Ćwiklicki i Przebinda 2016, s. 41]. Wychodząc z założenia, że kluczowym elementem koncepcji lean jest rozwinięcie u pracowników umiejętności identyfikacji marnotrawstwa w procesach i nauczenie ich sposobów jego eliminowania lub przynajmniej radykalnego ograniczania, A. Grycuk proponuje, aby marnotrawstwo występujące w sektorze publicznym poddać klasyfikacji w układzie analogicznym do tego, który zaproponował T. Ohno (tabela 1).

Tabela 1. Podstawowe kategorie marnotrawstwa w sektorze publicznym

\begin{tabular}{|l|l|l|}
\hline Rodzaj strat & \multicolumn{1}{|c|}{ Charakterystyka } & \multicolumn{1}{|c|}{ Przykłady } \\
\hline Nadprodukcja & $\begin{array}{l}\text { Wytworzenie czegoś z myślą } \\
\text { o przechowywaniu na później, } \\
\text { wykonanie pracy, na którą } \\
\text { w danym momencie nie ma zapo- } \\
\text { trzebowania }\end{array}$ & $\begin{array}{l}\text { Nieuzasadnione tworzenie przepisów } \\
\text { prawnych i zarządzeń, przygotowywanie } \\
\text { nikomu niepotrzebnych zestawień, genero- } \\
\text { wanie informacji bez właściwego rozezna- } \\
\text { nia potrzeb adresatów, produkowanie zbyt } \\
\text { dużej liczby druków biurowych }\end{array}$ \\
\hline Zapasy & $\begin{array}{l}\text { Wszystko to, co nie jest w danym } \\
\text { momencie niezbędne do realizacji } \\
\text { danego procesu pracy, lub to, co } \\
\text { jest potrzebne, lecz znajduje się na } \\
\text { stanowisku w zbyt dużej ilości }\end{array}$ & $\begin{array}{l}\text { Zbędne dokumenty, dokumenty w zbyt } \\
\text { dużej ilości, zapas czystego papieru lub } \\
\text { druków na stanowisku wystarczający na } \\
\text { wiele tygodni nieprzerwanej pracy, nad- } \\
\text { miar informacji }\end{array}$ \\
\hline \multicolumn{2}{|l}{} \\
\hline
\end{tabular}


cd. tabeli 1

\begin{tabular}{|c|c|c|}
\hline Rodzaj strat & Charakterystyka & Przykłady \\
\hline $\begin{array}{l}\text { Braki (błędy } \\
\text { i wady jako- } \\
\text { ściowe) }\end{array}$ & $\begin{array}{l}\text { Praca, która nie została wyko- } \\
\text { nana właściwie za pierwszym } \\
\text { razem i musi zostać poprawiona } \\
\text { lub klient ocenia ją jako usługę } \\
\text { o niskiej wartości }\end{array}$ & $\begin{array}{l}\text { Niewłaściwe decyzje administracyjne, } \\
\text { realizacja procedury niezgodnie z prze- } \\
\text { pisami prawa, udzielenie błędnych, } \\
\text { niekompletnych lub nieprawdziwych } \\
\text { informacji, niedotrzymanie terminów } \\
\text { realizacji procedur określonych w przepi- } \\
\text { sach, nieprawidłowo naliczone płatności, } \\
\text { błędy w korespondencji, zagubienie lub } \\
\text { zniszczenie dokumentów, niespójne lub } \\
\text { dwuznaczne prawo }\end{array}$ \\
\hline Oczekiwanie & $\begin{array}{l}\text { Sytuacje, w których dochodzi } \\
\text { do przestoju w pracy z powodu } \\
\text { opóźnienia realizacji zadań na } \\
\text { wcześniejszych stanowiskach, } \\
\text { niedostarczenie materiałów lub } \\
\text { informacji }\end{array}$ & $\begin{array}{l}\text { Oczekiwanie na podpis, decyzję czy } \\
\text { zezwolenie, przewlekłe postępowanie } \\
\text { administracyjne, opóźnienie we wdrażaniu } \\
\text { nowych przepisów lub narzędzi informa- } \\
\text { tycznych, brak materiałów biurowych lub } \\
\text { druków, przesuwanie wszystkich działań } \\
\text { na najpóźniejszy dopuszczalny termin }\end{array}$ \\
\hline $\begin{array}{l}\text { Nadmierne } \\
\text { przetwarzanie }\end{array}$ & $\begin{array}{l}\text { Wykonywanie pracy, która nie } \\
\text { jest konieczna do zrealizowania } \\
\text { określonej usługi lub wypełnienia } \\
\text { wymogów prawa }\end{array}$ & $\begin{array}{l}\text { Niepotrzebne lub zbyt rozbudowane } \\
\text { procedury, za daleko idąca kontrola, } \\
\text { gromadzenie niepotrzebnych informacji, } \\
\text { powtarzające się działania, nadmierne } \\
\text { regulacje prawne, nadmierna sprawoz- } \\
\text { dawczość, wykonywanie niepotrzebnych } \\
\text { kopii dokumentów, dyskusje na zebraniach } \\
\text { niewnoszące niczego do meritum sprawy }\end{array}$ \\
\hline $\begin{array}{l}\text { Zbędny } \\
\text { transport }\end{array}$ & $\begin{array}{l}\text { Przemieszczanie osób, przedmio- } \\
\text { tów lub dokumentów niegeneru- } \\
\text { jące wartości lub nieprowadzące } \\
\text { do postępu w realizowanej } \\
\text { procedurze }\end{array}$ & $\begin{array}{l}\text { Zbędne podróże służbowe, niepotrzebne } \\
\text { przesyłanie dokumentów, nieuzasadnione } \\
\text { wzywanie stron do osobistego stawien- } \\
\text { nictwa, zbyt niski stopień wykorzystania } \\
\text { technologii teleinformatycznych }\end{array}$ \\
\hline $\begin{array}{l}\text { Zbędny ruch } \\
\text { pracowników }\end{array}$ & $\begin{array}{l}\text { Ruch pracowników na stanowisku } \\
\text { pracy, którego można uniknąć }\end{array}$ & $\begin{array}{l}\text { Niewłaściwe rozmieszczenie przedmiotów } \\
\text { (wyposażenia) na stanowisku pracy, bała- } \\
\text { gan, słaba ergonomia stanowiska, prze- } \\
\text { mieszczanie się pracowników pomiędzy } \\
\text { nieracjonalnie rozmieszczonymi działami } \\
\text { w budynkach biurowych }\end{array}$ \\
\hline $\begin{array}{l}\text { Marnowanie } \\
\text { potencjału } \\
\text { pracowników }\end{array}$ & $\begin{array}{l}\text { Złe warunki do samorozwoju oraz } \\
\text { wykazania się przez pracowników } \\
\text { pomysłowością i kreatywnością } \\
\text { w doskonaleniu procesów, za któ- } \\
\text { rych realizację są odpowiedzialni }\end{array}$ & $\begin{array}{l}\text { Brak systemu motywującego do poszuki- } \\
\text { wania usprawnień, brak szkoleń, rezygna- } \\
\text { cja ze stosowania metod pracy zespołowej }\end{array}$ \\
\hline
\end{tabular}

Źródło: opracowanie własne na podstawie [Grycuk 2011, s. 3]. 


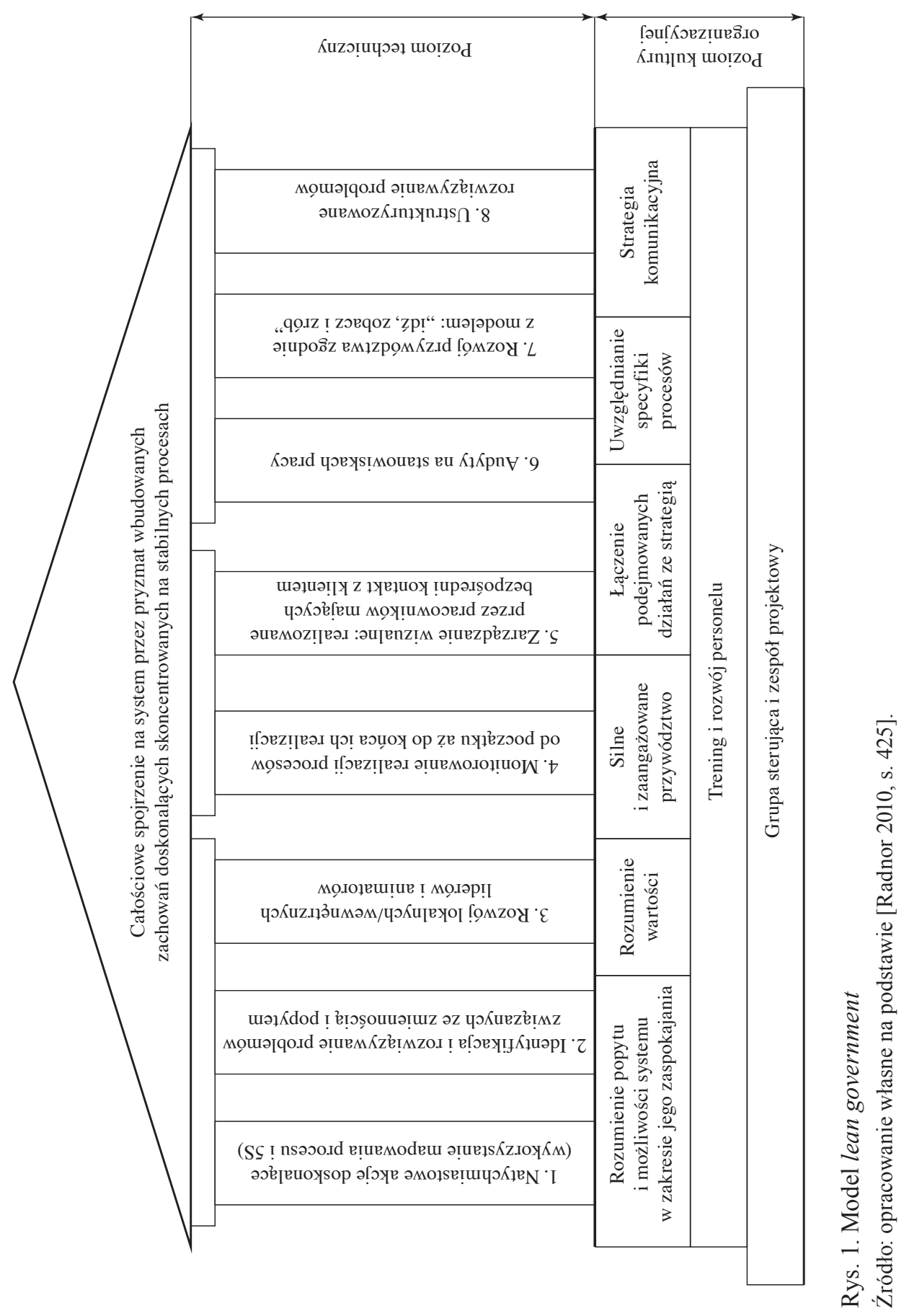


Inne spojrzenie na marnotrawstwo w przypadku procesów składających się w przeważającej mierze z czynności biurowych (w sensie obsługi administracyjnej procesów biznesowych) zaprezentowali J. Czekaj i B. Ziębicki. Autorzy ci wyróżnili następujące kategorie strat: ludzkie, procesowe, informacyjne, majątkowe oraz kierownicze [2015, s. 61-62]. Klasyfikacje kładące większy nacisk na procesy informacyjno-komunikacyjne oraz decyzyjne, zaś mniejszy na przepływ materiału, wydają się lepiej dopasowane do analizowanego obszaru, w którym kluczowe znaczenie ma przetwarzanie informacji oraz podejmowanie decyzji administracyjnych.

Zastosowane w sektorze publicznym podejście odchudzone nie będzie dokładną kopią lean management znanego z organizacji komercyjnych. Zdaniem Z. Radnor nie będą to jednak różnice fundamentalne co do podstawowych zasad [2010, s. 424], a raczej różnice związane z odmienną specyfiką funkcjonowania instytucji sektora publicznego. Kluczowe są odmienny cel funkcjonowania oraz usługowy charakter tychże instytucji (usługi cechują się koniecznością każdorazowego dostosowania do indywidualnych wymagań, tym samym ich standaryzacji nie można przeprowadzić w takim stopniu, jaki jest możliwy w przypadku procesów produkcyjnych).

Podobnie jak w lean management, także w lean government można wyróżnić dwa podstawowe poziomy, na których funkcjonuje system wykorzystujący koncepcję zarządzania odchudzonego (rys. 1).

Pierwszy poziom stanowi podbudowę. Są to elementy związane z tworzeniem kultury organizacyjnej i przygotowaniem organizacji na wdrożenie nowego podejścia. Mają one za zadanie dostosować strategię organizacji, ukształtować przywództwo, pożądane zachowania i zaangażowanie pracowników. Elementami tymi w prezentowanym modelu są grupa sterująca i zespół projektowy, a także program treningowo-szkoleniowy oraz systematyczny rozwój wiedzy personelu. Drugi poziom, określany mianem technicznego, tworzy osiem filarów grupujących metody i techniki pomocnicze dobrane do potrzeb instytucji sektora publicznego. Z. Radnor [2010, s. 425] dzieli je na trzy grupy. Trzy pierwsze filary (zob. rys. 1) obejmują narzędzia umożliwiające szybkie osiągnięcie postępu, koncentrację na wyznaczonych celach i zaangażowanie pracowników. Powinny one zostać wdrożone w pierwszej kolejności. Kolejne dwa filary to narzędzia umożliwiające monitorowanie osiąganych efektów, natomiast trzy ostatnie to metody i techniki zapewniające stosowanie głównych założeń koncepcji lean w codziennym funkcjonowaniu organizacji.

Zaprezentowany model przedstawia zatem w sposób obrazowy kolejność implementacji elementów lean government. Jeżeli poszczególne elementy będą wdrażane w przypadkowej kolejności, może się okazać, że uzyskane efekty będą rozczarowujące i w konsekwencji personel zrazi się do całej koncepcji. 


\section{Trudności związane z wdrażaniem lean government}

Podstawowe trudności związane ze stosowaniem podejścia odchudzonego w sektorze publicznym można podzielić na dwie kategorie, a mianowicie na wynikające z uwarunkowań wewnętrznych i zewnętrznych występujących w tym sektorze (tabela 2).

Tabela 2. Zewnętrzne i wewnętrzne bariery wdrażania lean government

\begin{tabular}{|c|l|}
\hline \multicolumn{1}{|c|}{ Bariery zewnętrzne } & \multicolumn{1}{c|}{ Bariery wewnętrzne } \\
\hline - brak konkurencji pomiędzy organizacjami & - ograniczona wiedza kierowników instytucji \\
sektora publicznego & sektora publicznego w zakresie nowocze- \\
- brak konieczności samofinansowania & snych rozwiązań organizacyjnych z sektora \\
działalności & komercyjnego \\
- trudność w analizowaniu produktu pod & - ograniczone możliwości w zakresie \\
kątem powiązanej z nim wartości & delegowania uprawnień (procedury ściśle \\
- uwarunkowania prawne utrudniające & określają osoby uprawnione do podejmowa- \\
efektywne eliminowanie marnotrawstwa & nia określonych decyzji) \\
z procesów & - niedostosowany do potrzeb lean system \\
- wywieranie wpływu na funkcjonowanie & motywacyjny (słabo rozwinięte mechani- \\
instytucji sektora publicznego przez poli- & zmy nagradzania pracowników za dobrze \\
tyków & realizowaną i efektywną pracę, jak również \\
& wyciągania konsekwencji w przypadku \\
& złego wykonywania obowiązków) \\
\hline
\end{tabular}

Źródło: opracowanie własne na podstawie [Walczak 2012, s. 157-159].

Przeszkody te należy uznać za podstawowe czynniki, ze względu na które występują różnice w stosowaniu podejścia odchudzonego między sektorem publicznym a organizacjami komercyjnymi. Oprócz nich istotne są również specyficzne cechy tego typu instytucji, do których Z. Radnor i S.P. Osborne zaliczają [2013, s. 268]:

- działalność nastawioną na usługi, a nie na wytwarzanie dóbr o charakterze rzeczowym,

- występującą w wielu przypadkach koncentrację procesów i systemów operacyjnych na efektach wewnętrznych (czyli wymaganiach np. innych działów), a nie zewnętrznych (czyli potrzebach końcowych użytkowników/konsumentów usług),

- stosowanie odmiennych, w porównaniu z sektorem komercyjnym, wskaźników sukcesu.

Istotnym wyzwaniem przy wdrażaniu zasad lean w sektorze publicznym jest niewątpliwie usługowy, a nie wytwórczy profil działalności. Produktem dostarczanym przez omawiany sektor są usługi (np. urzędy zajmują się przetwarzaniem i dostarczaniem informacji, szpitale świadczą usługi zdrowotne, spółki komunalne usługi na potrzeby społeczności zamieszkującej określoną gminę). 
W porównaniu z działalnością wytwórczą, czyli pierwotnym obszarem wykorzystania podejścia odchudzonego, usługi cechuje jednoczesność, niejednorodność, niematerialność i nietrwałość (simultaneity, heterogeneity, intangibility, perishability, w skrócie: SHIP) [Pająk, Klimkiewicz i Kosieradzka 2014, s. 47]. Jednoczesność, inaczej nierozłączność, to cecha usługi polegająca na tym, że jest ona w tym samym czasie świadczona, dystrybuowana i konsumowana. Oznacza to, że klient w większości przypadków musi być obecny podczas tworzenia usługi, a co więcej - powinien nawet współuczestniczyć w jej powstaniu. Niejednorodność (niejednolitość) polega na konieczności dopasowania usługi do indywidualnych wymagań konsumenta. Ponadto cecha ta w sposób istotny przekłada się na ocenę jakości świadczonych usług. Biorąc pod uwagę ocenę jakości usług, dokonywaną przeważnie z wykorzystaniem miar jakościowych, należy liczyć się z sytuacjami, gdy z takiego samego wykonania jeden klient będzie zadowolony, a drugi niekoniecznie. Poza oceną jakości niejednorodność rodzi również problemy w zakresie standaryzacji oraz wyznaczania cen usług. Niematerialność oznacza brak rzeczowego charakteru lub bardzo ograniczony rzeczowy charakter usług. W przypadku gdy produktem usług jest informacja, postać materialną najczęściej posiada jedynie nośnik, na którym informacja ta jest zapisana. Nietrwałość usług uniemożliwia ich przechowywanie. Transport również jest ograniczony w zasadzie do usług, które mogą być świadczone na odległość z wykorzystaniem technologii informacyjno-komunikacyjnych. Produkcję usługi rozpoczyna się zatem dopiero w momencie pojawienia zapotrzebowania na nią, a zatem dostawca usługi musi zapewnić odpowiednie zasoby tak, aby w sposób ciągły być przygotowanym na pojawienie się klienta [Pająk, Klimkiewicz i Kosieradzka 2014, s. 48].

Lean management był opracowywany z myślą o przedsiębiorstwach przemysłowych. Stąd też wiele wykorzystywanych w nim metod pomocniczych odnosi się do racjonalizacji funkcjonowania maszyn i urządzeń, czy też optymalizacji przepływu materiału przez system produkcyjny ${ }^{4}$. Do rozwiązań takich należy zaliczyć np.: program TPM, metodę SMED, technologię grupową, heijunka. Na odpowiednim poziomie ogólności nawet tak specjalistyczne narzędzia mogą jednak zostać z powodzeniem wykorzystane w doskonaleniu funkcjonowania urzędów administracji publicznej. Przykładowo TPM może znaleźć zastosowanie przy poprawie działania wyposażenia biurowego, a SMED może sprawdzić się w roli narzędzia usprawniającego obsługę klientów ${ }^{5}$.

${ }^{4}$ Najważniejsze metody i techniki wspomagające wdrożenie koncepcji lean zostały wymienione w pracy [Lisiński i Ostrowski 2006, s. 74-75].

5 Obszerną analizę możliwości wykorzystania metody SMED do usprawnienia obsługi klienta znaleźć można w pracy [Walczak 2007]. 


\section{Podstawowe wytyczne implementacji lean government}

J.P. Womack i D.T. Jones proponują, aby w przypadku przedsiębiorstw wdrożenie odchudzonego zarządzania podporządkowane było następującym pięciu zasadom [Womack i Jones 2001, s. 10]:

1) dokładnie ustalić wartość dla każdego produktu,

2) zdefiniować strumień wartości dla każdego produktu,

3) zapewnić niezakłócony przepływ wartości,

4) pozwolić klientom na wyciąganie wartości od producenta,

5) dążyć do doskonałości.

Ze względu na duży stopień ogólności zasady te można również wykorzystać przy formułowaniu wskazówek dotyczących implementacji lean government. Należy przede wszystkim zidentyfikować czynności dodające wartość, a wykorzystanie jakichkolwiek technik i metod wchodzących w skład lean management powinno być ukierunkowane na usprawnienie przepływu strumienia wartości w organizacji. J. Womack i D. Jones podkreślają, że najczęściej spotykanym błędem w aplikacjach praktycznych jest postrzeganie lean management przez zarządzających jedynie przez pryzmat metod, technik i zasad [Womack i Jones 2001, s. 10]. Takie rozumienie prowadzi do otrzymywania cząstkowych efektów odchudzania organizacji i uniemożliwia osiągnięcie wszystkich korzyści wynikających ze zrozumienia całości omawianego systemu. Błąd ten wynika po części $\mathrm{z}$ faktu publikowania przez japońskich twórców podejścia odchudzonego opisów poszczególnych metod i technik w oderwaniu od całościowego ujęcia umożliwiającego połączenie ich w spójny system zarządzania przedsiębiorstwem.

Zarządzanie przedsiębiorstwem w myśl ogólnych zasad lean koncentruje się na usprawnianiu procesów operacyjnych oraz tworzeniu kultury organizacyjnej ukierunkowanej na tworzenie wartości we wszystkich podejmowanych działaniach. Należy podkreślić również, że ocena wartości powstającej w procesach powinna być dokonywana z punktu widzenia klienta lub konsumenta, a nie organizacji i jej potrzeb wewnętrznych [Radnor i Osborne 2013, s. 268]. $\mathrm{Z}$ oceną tego typu $\mathrm{w}$ instytucjach sektora publicznego występują niejednokrotnie problemy. Przykładem może być kwestia informowania klienta o jego prawach na poszczególnych etapach postępowania administracyjnego. Tego typu informacje dołączane $\mathrm{w}$ formie pouczenia do pism dla klienta obeznanego w procedurze jest całkowicie zbędne (nie tworzy wartości), dla innego stanowią cenne wskazówki, jakie działania należy podjąć, aby sprawę załatwić.

Uporządkowaną listę szczegółowych wytycznych stosowania podejścia lean w sektorze publicznym zaproponowali Z. Radnor i S.P. Osborne [2013, s. 280-282]: 
1) kluczową kwestią jest koncentracja na tworzeniu wartości z punktu widzenia obywateli (czyli końcowych użytkowników/konsumentów usług publicznych). W tym kontekście podnoszenie efektywności procesów wewnętrznych jest istotne, ale nie jest to warunek zapewniający osiągnięcie sukcesu przy wdrażaniu lean government;

2) jakość usług zewnętrznych jest uwarunkowana jakością procesów wewnętrznych, poprawa usług świadczonych przez instytucje publiczne musi być zatem pochodną zmian procesów wewnętrznych tych instytucji;

3) ze względu na usługowy charakter sektora publicznego konieczne jest pełne zaangażowanie końcowych konsumentów usług zarówno w proces wdrażania podejścia odchudzonego, jak i samą produkcję usług. Istotne jest także kierowanie się zasadą, że to właśnie końcowy konsument ma być beneficjentem wszelkich zmian związanych z wdrożeniem lean government;

4) lean government, aby było efektywne, musi być stosowane jako kompleksowe rozwiązanie pociągające za sobą zmianę kultury organizacyjnej instytucji sektora publicznego, tak by była ona nastawiona na zaspokojenie potrzeb zewnętrznych (finalnych) użytkowników usług. Implementowanie pojedynczych narzędzi wspomagających lean nie przyniesie oczekiwanych efektów;

5) ważną zmianą związaną z wdrożeniem lean government jest zrozumienie przez pracowników, że najlepsze efekty przyniesie dzielenie się wiedzą z finalnymi użytkownikami usług oraz tworzenie warunków, aby wiedza ta była wykorzystywana do współtworzenia wartości w procesach przez samych finalnych użytkowników.

Autorzy wytycznych zastrzegli jednak, że zostały one sformułowane na podstawie analizy zaledwie kilku wdrożeń podejścia lean $\mathrm{w}$ instytucjach sektora publicznego i konieczne są dalsze badania w celu ich pełnej weryfikacji. Weryfikację tę utrudnia w szczególności duże zróżnicowanie sektora publicznego. Nie można wykluczyć, że istnieją pewne typy usług publicznych lub okoliczności ich świadczenia, w których koncepcja zarządzania odchudzonego będzie niewłaściwa [Radnor i Osborne 2013, s. 283].

Wskazówek odnośnie do praktycznej implementacji lean government dostarcza również analiza dobrych praktyk w tym zakresie. Na jej podstawie stwierdzono, że [Ćwiklicki i Przebinda 2016, s. 43]:

1) wdrożenie powinno przebiegać stopniowo, tzn. najpierw przeprowadzany jest pilotaż obejmujący wybrany fragment organizacji lub jej działania. Ukazanie zalet nowych rozwiązań i przekonanie personelu o ich słuszności w sposób istotny ułatwia wprowadzanie dalszych zmian;

2) we wszystkich przebadanych przypadkach inicjatywa wdrożenia lean government wyszła od kierownictwa najwyższego szczebla, które dokonywało również ewaluacji programu; 
3) istnieje niepewność co do czasu trwania wdrożenia. Jest on szacowany na okres od dwóch do pięciu lat (na podstawie próby przyjętej przez autorów przywoływanego opracowania). Pozytywne efekty pojawiają się jednak znacznie wcześniej - już po paru tygodniach od rozpoczęcia wprowadzania zmian;

4) wdrożenia dokonywały zespoły składające się z pracowników badanych organizacji. Powszechną praktyką było natomiast korzystanie ze wsparcia zewnętrznych konsultantów. Konsultanci prowadzili szkolenia zarówno dla liderów, jak i dla pozostałych członków zespołów, czuwali również, aby przyjmowane rozwiązania były zgodne $\mathrm{z}$ duchem lean;

5) narzędziami pomocniczymi najczęściej wykorzystywanymi przy wdrożeniach lean government były: mapowanie strumienia wartości, kaizen, $5 \times$ dlaczego, program $5 \mathrm{~S}$. Ważną rolę odgrywało również kierowanie się zasadami określonymi przez J.P. Womacka i D.T. Jonesa [2001, s. 10].

Przytoczone powyżej ogólne wnioski są efektem analizy ośmiu wdrożeń lean government $\mathrm{z}$ różnych krajów świata. Uzyskany na ich podstawie obraz wskazuje na ewolucyjny charakter koncepcji oraz znaczący udział pracowników w jej wdrażaniu. Pod tymi względami lean government nie odbiega od pierwowzoru.

\section{Podsumowanie}

W debacie nad kształtem sektora usług publicznych w Polsce najczęściej pojawiają się opinie o konieczności „odchudzenia” sektora publicznego przez ograniczenie wydatków oraz poprawie jakości funkcjonowania administracji publicznej, aby pod tym względem dorównać instytucjom państw Unii Europejskiej [Opolski i Modzelewski 2009, s. 34]. W tym kontekście lean government należy uznać za interesującą koncepcję. Niestety jak dotąd nie pojawiły się opisy tego typu wdrożeń w polskich jednostkach administracji państwowej, chociaż można takie znaleźć na temat organizacji z Kanady, USA, Szwecji, Szkocji, Wielkiej Brytanii [Ćwiklicki i Przebinda 2016, s. 43 i 45] oraz Hiszpanii [Barraza, Smith i Dahlgaard-Park 2009]. Powstaje pytanie, czy tego typu prób jeszcze w naszym kraju nie podejmowano. Jeżeli odpowiedź jest twierdząca, oznacza to, że polskie jednostki administracji publicznej są opóźnione pod tym względem np. w stosunku do swoich duńskich odpowiedników. Szacuje się, że w 2008 r. 56\% duńskich organizacji publicznych wykorzystywało lean, chociaż - co też należy zaznaczyć - jedynie w odniesieniu do wybranych procesów w ograniczonej liczbie jednostek [Pedersen i Huniche 2011, s. 410]. Stąd też wniosek, że czas najwyższy, aby w Polsce również zaczęto wprowadzać podobne rozwiązania.

Wdrożenie tej koncepcji nie może jednak polegać na kopiowaniu rozwiązań znanych z przedsiębiorstw wytwórczych, działających na rynkach cechujących 
się silną konkurencją. Wynika to z występowania specyficznych dla sektora publicznego barier oraz jego usługowego charakteru. W większym stopniu wdrożenie tej koncepcji obejmie procesy administracyjno-biurowe i decyzyjne oraz obsługę klienta. Problem ten został już dostrzeżony, powstały również wytyczne co do postępowania przy wdrożeniu. Pomocne może okazać się także odwołanie się do doświadczeń w stosowaniu koncepcji lean administration, wykorzystywanej w doskonaleniu podsystemów zarządzania przedsiębiorstw, w tym ich procesów informacyjno-komunikacyjnych [Czekaj i Ziębicki 2015, s. 64-65].

Należy mieć jednak świadomość, że nie wszystkie rozwiązania stosowane w sektorze komercyjnym będą sprawdzać się w sferze publicznej. Już w 1999 r. Generalne Biuro Audytorów poinformowało rząd australijski o problemach występujących przy wdrażaniu zasad stosowanych w przedsiębiorstwach do zarządzania usługami sektora publicznego [Opolski i Modzelewski 2009, s. 34], a część autorów, w tym wspomniany w początkowej części niniejszego opracowania H. Izdebski, wskazuje na zmierzch NPM, z którego założeń wyrasta lean government.

\section{Literatura}

Barraza M.F.S., Smith T., Dahlgaard-Park S.M. [2009], Lean-kaizen Public Service: An Empirical Approach in Spanish Local Governments, „The TQM Journal”, vol. 21, nr 2, https://doi.org/10.1108/17542730910938146.

Czekaj J., Ziębicki B. [2015], Metodyczne aspekty lean administration, „Przegląd Organizacji", nr 9.

Ćwiklicki M. [2004], T. Ohno (1912-1990) - twórca Systemu Produkcyjnego Toyoty, „Organizacja i Kierowanie”, nr 4.

Ćwiklicki M., Przebinda G. [2016], Dobre praktyki lean government, „Przegląd Organizacji”, nr 8.

Grycuk A. [2011], Lean government, czyli koncepcja szczupłego zarzadzania $w$ administracji publicznej, „Analizy BAS”, nr 3(47).

Izdebski H. [2007], Od administracji publicznej do public governance, „Zarządzanie Publiczne", nr 1.

Lisiński M., Ostrowski B. [2006], Lean management w restrukturyzacji przedsiębiorstwa, Antykwa, Kraków-Kluczbork.

Opolski K., Modzelewski P. [2009], Zarządzanie jakościa w ustugach publicznych, Wydawnictwo CeDeWu, Warszawa.

Pająk E., Klimkiewicz M., Kosieradzka A. [2014], Zarządzanie produkcja i ustugami, PWE, Warszawa.

Pedersen E.R.G., Huniche M. [2011], Determinants of Lean Success and Failure in the Danish Public Sector. A Negotiated Order Perspective, „International Journal of Public Sector Management", vol. 24, nr 5, https://doi.org/10.1108/09513551111147141.

Radnor Z. [2010], Transferring Lean into Government, ,Journal of Manufacturing Technology Management”, vol. 21, nr 3, https://doi.org/10.1108/17410381011024368. 
Radnor Z., Osborne S.P. [2013], LEAN. A Failed Theory for Public Services?, „Public Management Review”, vol. 15, nr 2, https://doi.org/10.1080/14719037.2012.748820.

Sasak J. [2013], Benchmarking procesów jako narzędzie doskonalenia administracji publicznej, ,Studia Ekonomiczne. Zeszyty Naukowe Uniwersytetu Ekonomicznego w Katowicach", nr 168.

Walczak M. [2007], SMED jako metoda racjonalizacji procesów masowej obstugi klienta, Akademia Ekonomiczna w Krakowie, Kraków (praca doktorska).

Walczak M. [2012], Implementation Barriers of Lean Philosophy in Public Administration [w:] Management Consulting for Business and Public Administration, eds M. Ćwiklicki, M. Jabłoński, V. Potočan, Cracow University of Economics Foundation, Cracow.

Womack J.P., Jones D.T. [2001], Odchudzanie firm. Eliminacja marnotrawstwa-kluczem do sukcesu, Centrum Informacji Menedżera, Warszawa.

\section{Improving Processes in Public Administration Using Lean Government (Abstract)}

The article examines the issue of lean government, a concept used to improve the functioning of public sector institutions. It first describes current trends in the public sector and the concept of new public management. It then defines lean government and classifies losses brought on by the specifics of public administration. It outlines key barriers to implementing the methods that have been used to improve commercial organisations, and presents guidelines for applying the lean approach in public sector organisations. The article concludes by looking at the need to introduce this concept in the organisations in Poland's public sector.

Keywords: public administration, lean government, new public management, processes improvement. 